\title{
The Impact of Perceived Environmental Uncertainty, Supply Chain Performance, and Integrated Domestic Economy : Plywood Manufacturer in Indonesia
}

\author{
Arry Hutomo MDKSP ${ }^{1}$ and Roja Fitridayani ${ }^{2}$
}

\begin{abstract}
In the past few years, Indonesia is the largest exporter of plywood, the binding constraint in this case that Indonesia exploits neither advantages of being large resources country nor its dynamics competitive supply chain and ability to adapt with perceived environmental uncertainty. This study investigates whether perceived environmental uncertainty within supply chain performance affect intregated domestic economy. Predictable variables can be part of basis to solve integrated domestic economy and that variables can be considered by plywood manufacturer in Indonesia to respond to environmental uncertainty and supply chain itself. In this study, plywood manufacturer has been investigated as research samples, that its have SNI ISO 2426.2:2008. Multivariate analytical technique has been chosen with Warp PLS 3.0 and all samples have met the criteria composite reliability and cronbach's alpha. The study finds both of supply chain performance and perceived environmental uncertainty as predictor latent variables have positive impact, but supply chain performance had large effect sizes value explained, that supply chain performance plays an important role in improving practical perspective integrated domestic economy of plywood manufacturer in Indonesia and offer as one of a government or corporate attention to set regulations and to manage plywood supply chain policy.
\end{abstract}

Keywords-Perceived Environmental Uncertainty, Supply Chain Performance, Integrated Domestics Economy.

\section{Introduction}

This previous papers focus on analysis of the demand market of Indonesia's plywood in Japan explained that Indonesia's plywood industry was develop rapidly in 1980s. Indonesia as one of the largest rainforest products exporter with vary of products. Inevitably, Indonesia's plywood industry is very high depending on the export market for survival and growth [1]. Last year, the industry has allocated about $80 \%$ of its output for the export market. In the non-oil sector, plywood still plays a very important role as a source of foreign exchange in addition to textiles [2]. However, Indonesia's foreign exchange earning of plywood exports have declined [2].

Arry Hutomo MDKSP

Widyatama University

Bandung, Indonesia.

Roja Fitridayani

Widyatama University

Bandung, Indonesia
Makarennu analyzed that happens because the plywood industry not only faces competition from plywood manufacturers in other countries, but also have to deal with uncontrolled competition between Indonesia's plywood exporters as well as the lack of competitiveness of its products, in this case the author tries to connect with some of the indicators in the perceived environmental uncertainty variable. Indonesia's plywood has lost its competitiveness in the international market due to the cost of production continues to grow (as a result of rising fuel prices and labor costs, coupled with the logistical problems of unceasing) and social issues such as looting, robbery, and social conflict in forest areas [2] in this case the author tries to connect with some of the indicators in the supply chain performance variable. The end of 2014, the market weakened [2]. Although it is no longer possible to maintain the largest plywood as a foreign exchange earner in the non-oil/gas, still has the potential to become one of the main foreign exchange earner, given that Indonesia's plywood still dominate the international market for hardwood plywood. Another thing that urge for Indonesia's plywood industry to do is to restructure the preparation of policies and better infrastructure. Business competition in the era of globalization is characterized by market instability, perceived environmental uncertainty (PEU), require companies to conduct both of competitive advantage in terms of price and quality [3].

To fix this, plywood industry are required to cooperate in the resources or competencies required of each company in generating demand needs and the needs of consumers through supply chain management. In addition, through cooperation among the companies expected the innovation process can be improved. One of the strategies that need to be done is to use agile supply chain provides an alternative strategy to win the global competition with excellence is based competitive consumer focus, quality, and agility competencies backed companies such as consumer involvement, inventory management, technology, product development, and responsibility environmentally responsible.

There are many local markets are segmented than integrated market in Indonesia. There are many reasons the domestic market segmentation as including strong power of local government, regional cultural differences, labor immobility, lack of economic infrastructure and an adequate logistics, and information barriers. According to a study, that the integrated domestic economy (IDE) is an important measure of a country's economic development [4]. Proper supply chain strategy that is widely believed to improve the performance of supply chain management. 
Ignoring the important concept of alignment means that a failure in the supply chain due to a mismatch between two or more general remain important factors, some environmental uncertainty propose a framework for designing appropriate strategies [5]. However, the proposed framework are still not match fit circumstances or economic policy in Indonesia.

Therefore, one motivation of this paper is to determine the uncertainty framework empirically examine how the alignment between supply chain performance indicators and environmental uncertainty with integrated domestic economy in Indonesia. Different supply chain strategies appropriate different environmental uncertainty. It is not enough simply a strategy improve supply chain performance in Indonesia's plywood industry without considering the alignment between supply chain strategy, environmental uncertainty and integrated domestic economy. Based on that problem, the purpose of this paper is to analyze, to investigates whether perceived environmental uncertainty within supply chain performance affect intregated domestic economy in Indonesia plywood factory, because all predictable variables and role-model can be part of basis to solve integrated domestic economy and that variables can be considered by plywood manufacturer in Indonesia to respond to environmental uncertainty and supply chain itself.

Our final contribution is seen the comprehensive nature of study. While many of individual hypotheses explored in this paper find support in previous studies, they have not been investigated in a combined single study and considered within a circumstance framework and a performance measurement. The remainder of the paper is organised as follows. The next section (Section 2) will present the relevant literature and hypotheses. This will be followed by the research method (Methodology) in Section 3 and analysis, results, and discussion in Section 4. The last section (Section 5) provides conclusions, limitations and suggestions or implication for the future research.

\section{Literature Review}

\section{A. Perceived Environmental Uncertainty and Supply Chain Performance.}

In this study, all variables are considered with three elements of chain uncertainty (i.e. Chain configuration, chain control structure, chain information systems, chain organization and governance structure), manufacturing uncertainty, and demand uncertainty in most studies [6] mentions according to his work's findings that various dimensions of environmental uncertainty are main issues that can influence on managing the supply chain processes. Measuring demand uncertainty is a key activity in supply chain planning [7]. So, every dimension should be measured thoroughly, and their impact on supply chain processes should be analyzed to achieve better performance results [8]. Previous studies have considered various manufacturing uncertainty dimensions for this concept that customer satisfaction [9], financial performance [10], and market performance [9] are more popular. Therefore, we used three dimensions for manufacturing uncertainty construct in this study: customer satisfaction, financial performance, and market performance. Based on the explanation above the authors discuss on variables through three dimensions as reflective indicators for perceived environmental uncertainty (PEU): supply uncertainty, manufacturing uncertainty, and demand uncertainty. Previous research that perceived environmental uncertainty had positive affect to supply chain performance i.e. quality, response time, cost/financial, productivity [11].This study argues reflective indicator above to define perceived environmental uncertainty as a construct latent variable (PEU) expect that participation is positively associated with supply chain performance (SCP).

$\mathrm{H} 1$ : Perceived environmental uncertainty (PEU) is positively associated with supply chain performance (SCP).

\section{B. Supply chain performance and integrated domestic economy.}

In short, a transformative development policy would be made up of integrated, evolving, and sustained process of reforming an institution to promote synergistic, dynamic, and lasting change. It would include the following key elements supply chain performance affect to integrated domestic economy as a latent variable:

- Reduce logistics costs by expanding public investment in roads, bridges, ports, harbors, water, power, and sanitation facilities through budget reallocation from consumption to investment. Previous research explained lack of integrated domestic economy is positively associated with lack of supply chain performance, it result from limited inter-regional trade [12] and barrier to transport and trade [13].

- Reduce transaction costs by normalizing operations of the financial system. Increase worker productivity by enhancing the quality of knowledge and learning. Previous research explained substantial regional differences in average earning [14] and price differential equal to market fragmentation are identified as lack of an integrated domestic economy and highly affect the continuity the supply chain, its can even make unfavorable [15]. So, the author tries to assume that reflective indicator to explain the integrated domestic economy are limited inter-regional trade; barrier to transport and trade; substantial regional differences in average earning; and price differential equal to market fragmentation.

Author therefore expect that supply chain performance target will lead to higher integrated domestic economy

$\mathrm{H} 2$ : Supply chain performance (SCP) is positively associated with integrated domestic economy (IDE).

\section{Perceived environmental uncertainty and integrated domestic economy.}

In this study, we attempted to enhance what is known about previous research. All PEU indicators above such as chain uncertainty, manufacturing uncertainty and demand uncertainty will be stimulate chain configuration; chain 
control structure; chain information systems; chain organization governance structure; customer satisfaction; financial performance; market performance. All stimulate productive work for all Indonesians through expansion of the private sector and realign center-subnational administrative and fiscal arrangement in most appropriate allocation of respective roles and responsibilities; mention the ambiguity policy implementation AEC 2015 are part of perceived environmental uncertainty. Logically, the uncertainty is difficult to translate in the form of a state that will come, the model which existing with approach models can not necessarily predict one thing for sure. So, some of the assumption that strong are necessary. In this study, the author only consider from previous research that has a direct relationship with lack of integrated domestic economy.

Without an integrated dynamics domestic market, Indonesia has systematically missed the opportunity to benefit from having a large population. More importantly, much of the country's large population has been seen systematically excluded from the benefits of growth and development [12]. The original pattern of growth literature distinguished countries with large populations precisely because of the advantages of scale and scope derived from their large internal market [16]. When the market is very small, no person can have encouragement to dedicate himself entirely to one employment, this lowers the potential for productivity growth, uncertainty condition [17]. Indonesia has failed to take advantage of its large population and generally has few interregional demand spillovers [18]. So, this has undermined the country's capacity for income generation and employment creation uncertainty [12]. Therefore, in this study expect that perceived environmental uncertainty is positively associated with integrated domestic economy.

H3: Perceived environmental uncertainty (PEU) is positively associated with integrated domestic economy (IDE).

Our final contribution is seen in the comprehensive nature of the study. While many of the individual hypotheses explored in this paper find support in previous studies, they have not been investigated in a combined single study and considered within a performance measurement and evaluation framework. The model employed (constructs variables) in our study is depicted in Fig. 1.

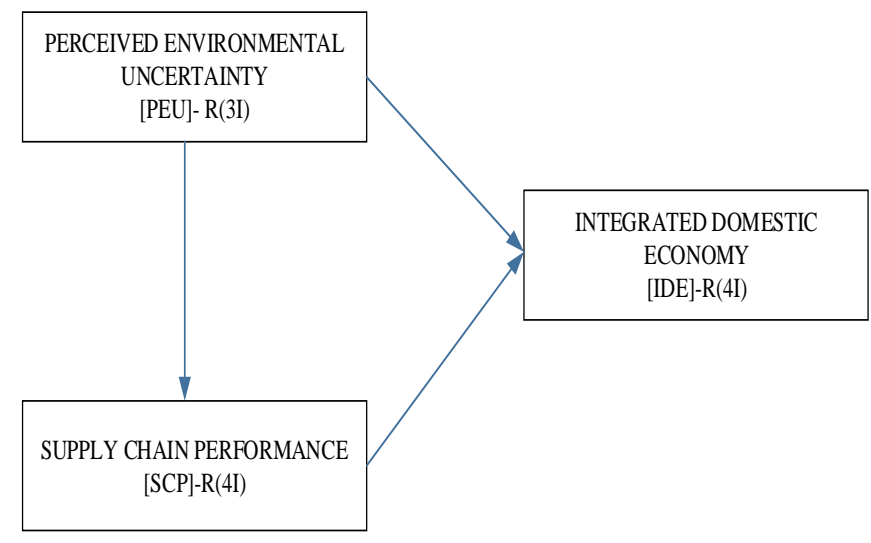

Figure 1. Model of the study - The impact of PEU, SCP associated with IDE

\section{METHODOLOGY}

\section{A. Research Setting and Sample.}

The study employs a sample of functional managers of plywood manufacturers. The time required by researcher starting from the preparation to become a final paper require almost 8.5 months (7 month collected data). A total of 89 questionnaires, together submit with covering letter each explaining the purpose of the study and assuring data confidentially, were sent to all functional managers representing all factory using internal organization's mailing system which it is have SNI ISO 2426.2:2008. This standard is identical to the result of the adoption of the translation method ISO 2426-1: 2000, Classification by surface appearance - Part 1: General. Part of the ISO 2426 standard contains general rules for the classification of plywood under the surface appearance. This standard is not used for plywood overlay.

The most of responses, however, were sent directly to researchers, and 19 respondents asked to be able to present the details of the study research interests to Managing Director. All data collection, the author was assisted by students as co-authors and to collect data assisted by staff of the Environment and Forestry Ministry RI, DH Consulting team to speed up data retrieval. This produced a total of 89 responses. Careful inspections of the responses, however, led to 3 respondents being dropped as unusable, yielding a final total of 86 responses (research samples) for analysis (a 96.62 percent response rate). In addition to the survey, interview discussions were conducted with 19 manager factory which minimum more than 7 years following all $S N I$ ISO 2426.2:2008 involved in the survey to ensure reliability of the survey responses and to gain a better understanding of managers perceptions of the impact of PEU, SCP associated with IDE.

\section{B. Instruments}

To enhance the validity and reliability of the construct and permit comparability of the results with previous studies, all variables were measure by instruments that had been previously developed and using a 5-point Likert-type scale, ranging from strongly disagree to strongly agree. The results of descriptive statistics of variables studied which cover mean, minimum and maximum values (both theoretical and actual), and the standard deviation.

To analysis all instruments we conduct goodness of fit model, estimates: (a) Output path coefficients and P-Value, (b) Output standard errors and effect sizes for path, (c) Output combined loading and cross-loadings, (d) Output pattern loadings and cross-loadings, (e) Output indicator weight, (f) Output latent variable coefficients, (g) Output correlations among latent variables, and the last (h) Output linear and non-linear relationship among latent variables.

\section{ANALYSIS AND RESULTS}

To test the hypotheses, a structural equation modeling (SEM) with partial least squares (PLS) approach was employed because it is able to deal with multiple dependent and independent variables simultaneously. In addition, PLS 
was considered suitable because it can handle relatively small sample sizes and multicollinearity among independent variables. Another important reason for using PLS is that it does not require a normal distributional assumption [19]. In this study we used PLS Graph (WarpPLS 3.0) software. The parameter estimation procedure associated with covariancebased structural equation modeling is not appropriate [19]. PLS is a component-based modeling technique which simultaneously examines both measurement and structural models.

The measurement model specifies the relationship between the manifest items (indicators) and the latent variables (constructs) they represent, see Table. 1. In other words, the measurement model assesses the reliability and validity of measures (indicators) relating to specific construct [19]. The output shows the goodness of fit criteria have been met and that the models of the APC values of 0.525 and 0.572 as well as significant ARS. AVIF value of 1.841 also have met the criteria, so this is the best models of (competing models). By checking the output path coefficients and P-values are shown in Table. 2 that the path coefficient of perceived environmental uncertainty, PEU had positive affect to integrated domestics economy, the IDE is for 0.328 and significant at 0.002 .Supply chain performance, SCP dominant positive effect (0.576) on the integrated domestic economy, IDE and significant with a $\mathrm{p}$ value of $<0.001$.

Output measurement standard errors and effect sizes path coefficient is done by looking at the effect size can be grouped into three categories: weak $(0.02)$, medium $(0.15)$, and large (0.35) [20]. The results showed the effect size estimate the effect of PEU to the SCP is 0.449 , PEU to the IDE for 0.235 and SCP to the IDE is 0.459 . These results include a large group of effect size indicating that PEU, SCP has an important role from determining a practical perspective in the IDE. Convergent validity test questionnaire instrument or outer constructs a model show the column and the indicators on the line. In test results outer models to construct reflective had convergent validity that the entire value of loading above 0.70 ( $\mathrm{P}$ value $<0.001$ ). If all the indicators that the value of the larger loading to construct where the cross-loading to other constructs lower. The results of this cross-loading can also be an indication of discriminant validity criteria are met. Q-squared is greater than zero. The results of our estimation models shows good predictive validity $(\mathrm{SCP}=0449$ and $\mathrm{DEP}=0.694)$. On Table. 1 is shown that output present two research instruments that measure the reliability of composite reliability and Cronbach's alpha. Both are worth over 0.70 values AVE above 0.50. In this study, researchers had measure full collinearity VIF value of output less than 3.3 so that the models is free from the problem of collinearity vertical, lateral and common method bias. By paying attention to its structure loading PEU-3 (0.787) has a large value followed by PEU-2 and PEU-1, and then SCP-2 (0.900) followed by SCP-3, SCP-1 and SCP-4 and last reviewed IDE-4 (0.660) followed by IDE-2, IDE-1 and IDE-3.

Variables through three dimensions as reflective indicators for perceived environmental uncertainty (PEU): supply uncertainty, manufacturing uncertainty, and demand uncertainty is positively associated with supply chain performance (SCP). Supply chain performance (SCP) is positively associated with integrated domestic economy (IDE) and perceived environmental uncertainty (PEU) is positively associated with integrated domestic economy (IDE).

TABLE I. THE MEASUREMENT MODEL SPECIFIES

\begin{tabular}{|c|c|c|c|c|}
\hline No & $\begin{array}{c}\text { Latent } \\
\text { Variables } \\
\text { (constructs) }\end{array}$ & $\begin{array}{l}\text { Manifest } \\
\text { Variables } \\
\text { (reflective } \\
\text { indicators) }\end{array}$ & $\begin{array}{c}\text { Cronbach's } \\
\text { Alpha }\end{array}$ & $\begin{array}{l}\text { Composite } \\
\text { Reliability }\end{array}$ \\
\hline 1 & $\begin{array}{c}\text { Perceived } \\
\text { Environmental } \\
\text { Uncertainty } \\
(P E U)\end{array}$ & $\begin{array}{l}\text { Chain uncertainty } \\
\text { (PEU-1); } \\
\text { Manufacturing } \\
\text { uncertainty (PEU- } \\
\text { 2); Demand } \\
\text { uncertainty (PEU- } \\
\text { 3). }\end{array}$ & 0.709 & 0.802 \\
\hline 2 & $\begin{array}{l}\text { Supply Chain } \\
\text { Performance } \\
\quad(S C P)\end{array}$ & $\begin{array}{l}\text { Quality (SCP-1), } \\
\text { response time } \\
(S C P-2), \\
\text { cost/financial } \\
\text { (SCP-3), } \\
\text { productivity } \\
(S C P-4)\end{array}$ & 0.914 & 0.940 \\
\hline 3 & $\begin{array}{c}\text { Integrated } \\
\text { Domestic } \\
\text { Economy }(I D E)\end{array}$ & $\begin{array}{l}\text { Limited inter- } \\
\text { regional trade } \\
\text { (IDE-1); barrier } \\
\text { to transport and } \\
\text { trade (IDE-2); } \\
\text { substantial } \\
\text { regional } \\
\text { differences in } \\
\text { average earning } \\
\text { (IDE-3); price } \\
\text { differential equal } \\
\text { to market } \\
\text { fragmentation } \\
\text { (IDE-4). }\end{array}$ & 0.792 & 0.865 \\
\hline
\end{tabular}

TABLE II. LATENT VARIABLE CORRELATIONS , EFFECT SIZES PATH COEFFICIENTS AND EFFECT SIZES FOR TOTAL EFFECTS

\begin{tabular}{|c|c|c|c|c|}
\hline & & $P E U$ & $S C P$ & $I D E$ \\
\hline \multirow{5}{*}{$\underset{2}{2}$} & Path Coefficients & & & \\
\hline & Effect Sizes for Path Coefficients & & & \\
\hline & Latent Correlations & & 0.659 & 0.709 \\
\hline & Effect Sizes for Total Effects & & & \\
\hline & $P$ Values for Correlation & 1.000 & $<0.001$ & $<0.001$ \\
\hline \multirow{5}{*}{$\underset{\sim}{2}$} & Path Coefficients & 0.670 & & \\
\hline & Effect Sizes for Path & 0.449 & & \\
\hline & Latent Correlations & 0.659 & & 0.759 \\
\hline & Effect Sizes for Total Effects & 0.449 & & \\
\hline & $P$ Values for Correlation & $<0.001$ & 1.000 & $<0.001$ \\
\hline \multirow{5}{*}{ s } & Path Coefficients & 0.328 & 0.576 & \\
\hline & Effect Sizes for Path & 0.235 & 0.459 & \\
\hline & Latent Correlations & 0.709 & 0.759 & \\
\hline & Effect Sizes for Total Effects & 0.512 & 0.459 & \\
\hline & $P$ Values for Correlation & $<0.001$ & $<0.001$ & 1.000 \\
\hline
\end{tabular}

Interpretation of the nonlinear relationship between supply chain performance and integrated domestic economy, in the beginning SCP policies would lead to the IDE variable tends to decrease, but at -1.5 points are shown in Fig. 2, it is made possible takes time for plywood industries to make adjustments, if SCP policies continuously improved then it integrated domestic economy will be better. 


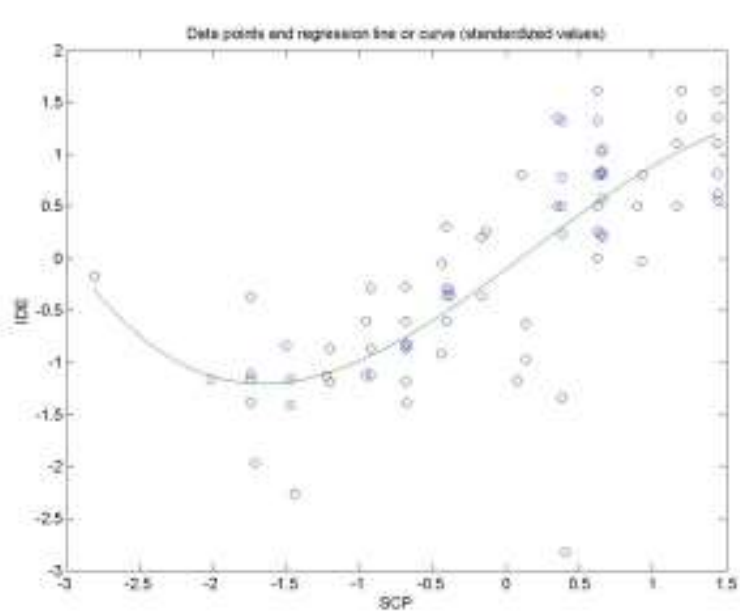

Figure 2. Output plot supply chain performance and integrated domestic economy

\section{v. CONCLUSION}

This study investigates whether perceived environmental uncertainty within supply chain performance affect intregated domestic economy. Using a sample of 86 plywood factory the study finds that supply chain performance (SCP) and perceived environmental uncertainty (PEU) is positively associated with integrated domestic economy (IDE). In details, demand uncertainty (PEU-3) and response time distribution (SCP-2) for plywood can be used as a basic priority to determine price differential equal to market fragmentation (IDE-4). However, due to supply chain performance more plays an important role in improving practical perspective integrated domestic economy of plywood manufacturer in Indonesia, then it priorities attention performance that should becoming further successive governments to solve so some constraints that cause plywood industries lack of an integrated domestics economy. The challenge government is to foster the constructive politics (critical infrastructure to be accelerated). To determine price differential equal to market fragmentation, government must identify bottlenecks are intensifying and its regional development is becoming more disintegrated and unbalanced. These are an offer as one of a government or corporate attention to set regulations and to manage plywood supply chain policy.

\section{Acknowledgment}

An appreciation is given to the Ministry of Environmental and Forestry Indonesia, DH Consulting for their data support and wish to acknowledge of Widyatama University in financial support.

\section{References}

[1] Tachibana S. "Impacts of logs export restrictions in Southeast Asia on the Japanese plywood market": An econometric analysis. Journal of forest research 2000; pp.51-57.

[2] Makarennu, Nakayasu A, Ichikawa M, "An analysis the demand market of Indonesian plywood in Japan." International Journal Sustainable Future of Human Society vol. 2, pp. 2-7, 2014.

[3] Hosseini S.M, Sheikhi N, An Empirical Examination of Competititve Capability's Contribution toward Firm Performance: Moderating Role of Perceived Environmental Uncertainty. International Business Research Vol.5 No.5, May 2012, pp.116-131.

[4] Dick, Howard W. (2002) "State, nation-state and national economy,"Ch. 1 in Howard Dick et al. The Emergence of a National Economy, An Economic History of Indonesia, 1800-2000, Honolulu: Allen \& Unwin and University of Hawaii Press.

[5] Xiaoling Zhang, Qiang Lu \& Teresa Wu. Petri-net based applications for supply chain management: an overview. International Journal of Production Research, Volume 49, Issue 13, 2011, pp. 3939-3961.

[6] Merrschmann, U., \& Thonemann, U.W. (2010). Supply Chain Flexibility, Uncertainty and Firm performance: An Empirical Analysis of German manufacturing Firms. International Journal of Production Economics, 130(1),pp. 43-53.

[7] Ministry of Trade Republic of Indonesia. Craft of the finest: Indonesian plywood. Export News Indonesia 2009;5:8.

[8] Ho, C-F., Chi, Y-P., \& Tai, Y-M. (2005). A Structural Approach to Measuring Uncertainty in Supply Chain. International Journal of Electronic Commerce, 9(3), pp.91-114.

[9] Kim, S. W. (2009). An Investigation on the direct an indirect effect of supply chain integration on firm performance. The International Journal of Production Economics, 119, pp.328-346.

[10] Oghazi, P. (2009). An Empirical Study of Swedish Nanufacturing Firms' Enterprise System Adoption. Supply Chain Integration, Competition Capability and Performance. (Doctoral Thesis). Lulea Uniersity of Technology, Swedish, pp. 1-203.

[11] Thongrattana, P. \& Jie, F. (2009). Identifying Sources of Perceived Environmental Uncertainty Along Thai Rice Supply Chain. 3rd International Conference on Operations and Supply Chain Management (pp.1-14). Malaysia: OSCM.

[12] Firdaus, Muhammad and Amalia A Widyansanti, (2010) "Indonesia Interprovincial Trade: What can be Revealed from a Gravity Modeling?" PPT Presentation at the Tenth IRSA (Indonesia Regional Science Assocaition) International Conference, Surabaya July 28-29.

[13] Lubis, Harun Al Rasyid, S. et al. (2005) "Multimodal Transport in Indonesia: Recent Profile and Strategy Development,"Proceedings of the Eastern Asia Society for Transportation Studies, vol 5, pp.46-64.

[14] Cornwell, Katy and Titik Anas (2013) "Survey of Recent Developments," Bulletin of Economic Studies, vol. 49, no.1, pp.7-33.

[15] Sumantri, Yeni and Sim Kim Lau (2011) “ The Current Status of Logistics Performance Drivers in Indonesia: An Emphasis on Potential Contributions of Logistics Service Providers (LSPs),"Journal of Asia Pacific Business Innovation \& Technology Management, vol. 1, pp.34-50.

[16] Chenery, Hollis B. and Moises Syrquin (1975) Pattern of Development 1950-1970 London: Oxprod University Pres for the World Bank.

[17] Smith, Adam (1776) An Enquiry into The Nature and Causes of the Wealth of Nations, New York: The Modern Library (edited with notes by E. Cannan 1937)

[18] BAPPENAS (2011) “ Infrastructure Development Strategy in Indonesia,"PPoint Presentation, Ministry of National Development Planning, National Development Planning Agency, Jakarta, January,pp.13.

[19] Chin, W (1998). The partial least squares approach to structural equation modeling. In G.A. Markoulides (Ed). Modern Methods for Business Research, pp. 295-336.

[20] Hair, J. F., Black, W. C., Babin, B. J., Anderson, R.E., \& Tatham, R. L.,(2006). In Multivariate data analysis (6th ed.). Pearson Education, Inc.

About Author (s):

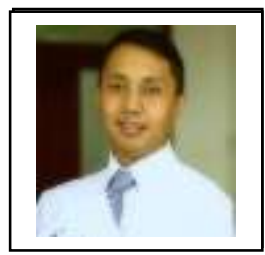

Arry Hutomo MDKSP is currently affiliating with Widyatama University as a lecturer and practitioner. His research interests include supply chain, operation research-optimization, business relationship management, decision techniques for logisticstransportation infrastructures. 